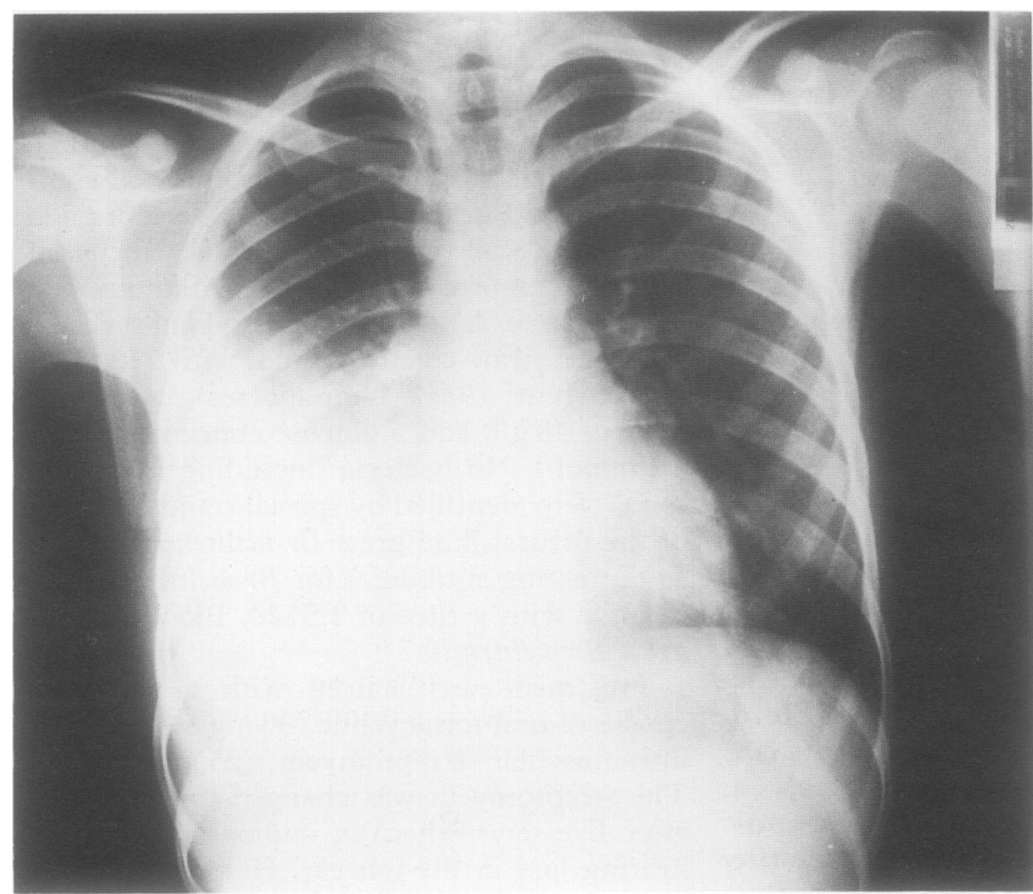

Area of consolidation in the right lower lobe and pleural effusion.

reaction. This was associated with a loculated effusion as seen with ultrasonography, indicating an organising process. We speculate that the absence of polymorphonuclear cells in the pleural space was associated with the favourable response to conservative treatment.

Although $\mathrm{Br}$ abortus is less virulent than $\mathrm{Br}$ melitensis and generally causes a milder disease, systemic and localised manifestations have been reported. To our knowledge pulmonary disease caused by $\mathrm{Br}$ abortus has been reported only once, ${ }^{6}$ and in that report the patient had diffuse interstitial fibrosis and hilar lymphadenopathy.

We conclude that $\mathrm{Br}$ melitensis should be added to the long list of microorganisms causing an exudative lymphocyte predominant pleural effusion. Although direct infection of the pleura occurs, conservative treatment with antibiotics may be sufficient.

1 Lulu AR, Arab GF, Khateeb MI, Mustafa MY, Yusuf AR, Fenech FF. Human brucellosis in Kuwait: a prospective study of 400 cases. $Q \mathcal{F}$ Med 1988;66:39-54.

2 Lubani MM, Dudin KI, Sharda DC, et al. A multicenter therapeutic study of 1100 children with brucellosis. Pediatr Infect Dis f 1989;8:75-8.

3 Lubani MM, Lulu AR, Araj GF, Khateeb MI, Qurtom MAF, Dudin KI. Pulmonary brucellosis. $Q \mathcal{F}$ Med 1989;71:319-24.

4 Kaufmann AF, Fox MD, Boyge JM, Anderson DC, Potter ME, Martone WJ, et al. Airborne spread of brucellosis. Ann NY Acad Sci 1980;353:105-14.

5 Ruben B, Band JD, Wong P, Colville J. Person to person transmission of Brucella melitensis. Lancet 1991;337:14-5. transmission of Brucella melitensis. Lancet 1991;337:14-5.
Harvey WA. Pulmonary brucellosis. Ann Intern Med Harvey WA. Pulmo
1948;28:768-81.

Greer AE. Pulmonary brucellosis. Dis Chest 1956;29:50819.

8 Haden RL, Kyger ER. Pulmonary manifestations of brucellosis. Cleve Clin $Q$ 1946;13:220-7.

9 Garcia-Rodrigez JA, Garcia-Sanchez JE, Munoz Bellido Jl, Ortiz de la Tabla V, Bellido Barbero J. Review of pulmonary brucellosis: a case report on brucella pulmonary empyema. Diagn Microbiol Infect Dis 1989;11:53-60.

10 Sharda DC, Lubani MM. A study of brucellosis in childhood. Clin Pediatr 1986;25:492-5.

\section{Response to ketamine in status asthmaticus resistant to maximal medical treatment}

\author{
Anne Hemming, Iain MacKenzie, \\ Simon Finfer
}

\section{Intensive Therapy \\ Unit, John Radclifie \\ Hospital, Oxford \\ OX3 9DU \\ A Hemming \\ I MacKenzie \\ $S$ Finfer}

Reprint requests to: Dr S Finfer, Consultant in Intensive Therapy, Royal North Shore Hospital, St Leonards, New South Wales 2065, Australia.

Received 15 December 1992 Returned to authors 2 February 1993 Revised version received 26 February 1993 Accepted for publication 10 March 1993

\begin{abstract}
The case is reported of a 28 year old woman with status asthmaticus unresponsive to three days of maximal medical treatment. Resolution of bronchospasm was achieved with an infusion of the intravenous anaesthetic agent ketamine.
\end{abstract}

(Thorax 1994;49:90-91)

Ketamine is a unique intravenous anaesthetic agent with sedative, analgesic, and bronchodilator properties. Its propensity to cause distressing emergence phenomena has limited its use. It has been used successfully in patients with acute asthma ${ }^{1-4}$ but these patients had not received maximal medical treatment as judged by current standards. The treatment of acute asthma is outside the terms of its UK product licence and its role in this setting remains to be defined. This report describes its successful use in a patient in whom conventional medical treatment had failed.

\section{Case report}

A 28 year old woman with a history of asthma was admitted unconscious having suffered a respiratory arrest at home. Endotracheal intubation was performed immediately, arterial blood gases following intubation were pH 6.93, $\mathrm{PaCO}_{2} 14.1 \mathrm{kPa}, \mathrm{PaO}_{2} 14.0 \mathrm{kPa},\left(\mathrm{FIO}_{2}\right.$ 1.0). Initial treatment was with intravenous hydrocortisone $200 \mathrm{mg}$, aminophylline $250 \mathrm{mg}$, and ventilation by hand with $1 \%$ halothane in oxygen. In the intensive care unit treatment was continued with intravenous aminophylline $0.9 \mathrm{mg} / \mathrm{kg} / \mathrm{hour}$, hydrocortisone $200 \mathrm{mg}$ every six hours, and nebulised ipratropium bromide $500 \mu \mathrm{g}$ four hourly. Mechanical ventilation 


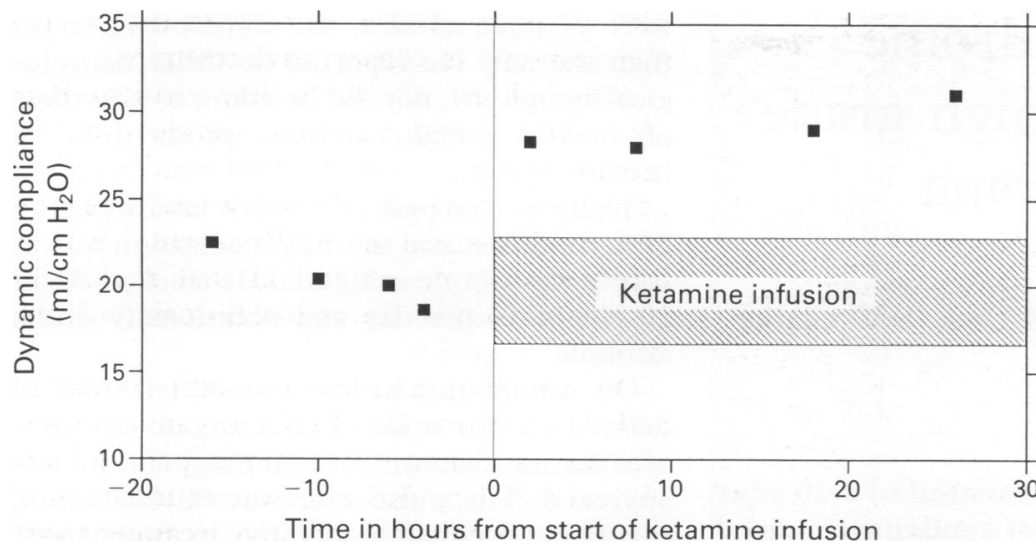

Change in dynamic compliance with ketamine.

was commenced and tidal volume was adjusted to limit peak inspiratory pressure to $30 \mathrm{~cm}$ $\mathrm{H}_{2} \mathrm{O}$. A chest radiograph showed a right mid zone infiltrate but no pneumothorax. She remained ventilator dependent for the next four days during which the bronchospasm persisted despite the addition of intravenous salbutamol and inhaled isoflurane. To avoid excessive peak inspiratory pressure tidal volume had to be $400 \mathrm{ml}$ or less, $\mathrm{PaCO}_{2}$ varied between 6.4 and $8.6 \mathrm{kPa}$. After 72 hours treatment was with hydrocortisone $200 \mathrm{mg}$ six hourly, aminophylline $0.5 \mathrm{mg} / \mathrm{kg} /$ hour, salbutamol $10 \mu \mathrm{g} /$ minute, ipratropium bromide $500 \mu \mathrm{g}$ four hourly, and $2 \%$ isoflurane. Sedation and intermittent neuromuscular blockade were continued as attempts to reduce the level of sedation exacerbated the patient's bronchospasm. On day 4 the isoflurane was discontinued and an intravenous infusion of ketamine commenced at a dose of $2.5 \mathrm{mg} / \mathrm{kg} /$ hour. Within six hours the patient's chest was clear to auscultation, and gas exchange and respiratory system compliance had improved (figure). Spontaneous ventilation was established and the patient was successfully extubated 26 hours after starting the ketamine infusion; the ketamine was then discontinued. The patient regained consciousness over the following 36 hours and experienced no emergence phenomena. There was no recurrence of bronchospasm and the patient was discharged to the ward.

\section{Discussion}

Approximately $3 \%$ of patients admitted to hospital with asthma will require mechanical ventilation and most respond to treatment with conventional bronchodilators. Deaths in patients with asthma requiring mechanical ventilation may be caused by anoxic encephalopathy (usually due to a cardiac arrest occurring before mechanical ventilation is established), barotrauma, or sepsis. ${ }^{5-7}$ The risk of barotrauma may be reduced by limiting peak inspiratory pressure while adjusting ventilation to ensure adequate oxygenation, although some hypercarbia may have to be accepted. This strategy, which has been referred to as controlled hypoventilation or permissive hypercarbia, is based on the knowledge that hypercarbia is well tolerated where- as barotrauma contributes to a significant number of deaths. Adopting this strategy has produced good results in the management of both adults and children with asthma. ${ }^{78}$ Prolonged endotracheal intubation and invasive vascular monitoring increase the risk of sepsis and barotrauma. Aggressive treatment of asthma to allow early tracheal extubation and removal of intravascular lines may reduce morbidity and mortality. The British Thoracic Society has published guidelines for the management of severe acute asthma in adults ${ }^{9}$ and our patient was managed according to these guidelines but failed to improve over three days. There are few published data on which to base the management of patients who fail to respond to maximal conventional therapy. The volatile anaesthetic agents are potent bronchodilators and have been used successfully. ${ }^{10-12}$ Ether has traditionally been used, its major advantage being that it does not cause hypotension, but it is inflammable and explosive which poses a significant risk to the patient. Halothane, enflurane and isoflurane have all been used and there are no data to support the use of one agent in preference to the others. Isoflurane has a wider therapeutic index and is the agent of first choice in our unit. Our patient failed to respond to prolonged administration of isoflurane and was therefore treated with a ketamine infusion. Ketamine is licensed for use as an intravenous anaesthetic agent but not as a sedative or bronchodilator in intensive care. Previous unlicensed use of anaesthetic agents in intensive care has been associated with increased mortality. ${ }^{1314}$ We believe that ketamine should only be used when a patient has failed a trial of maximum conventional treatment but our experience suggests that systematic evaluation of its use in resistant status asthmaticus is justified.

1 Rock MJ, De la Rocha SR, L'Hommedieu CS, Truemper E. Use of ketamine in asthmatic children to treat respiratory failure refractory to conventional therapy. Crit Care atory failure refractory

2 Strube PJ, Hallam PL. Ketamine by continuous infusion in status asthmaticus. Anaesthesia 1986;41:1017-9.

3 Fisher MM. Ketamine hydrochloride in severe bronchospasm. Anaesthesia 1977;32:771-2.

4 Sharma VJ. Use of ketamine in acute severe asthma. Acta Anaesthesiol Scand 1992;36:106-7.

5 Scoggin CH, Sahn SA, Petty TL. Status asthmaticus. A nine-year experience. $\mathcal{F} A M A$ 1977;238:1158-62.

6 Luksza AR, Smith P, Coakley J, Gordan IJ, Atherton ST. Acute severe asthma treated by mechanical ventilation: 10 years' experience from a district general hospital. Thorax 1986;41:459-63.

7 Stein R, Canny GJ, Bohn DJ, Reisman JJ, Levison H. Severe acute asthma in a pediatric intensive care unit: six years' experience. Pediatrics 1989;83:1023-8.

8 Darioli R, Perret C. Mechanical controlled hypoventilation in status asthmaticus. Am Rev Respir Dis 1984;129:385-7.

9 Statement by the British Thoracic Society, Research Unit of the Royal College of Physicians of London, King's Fund Centre, National Asthma Campaign. Guidelines for management of asthma in adults II: Acute severe asthma. BMF 1990;301:797-800.

10 Robertson CE, Steedman D, Sinclair CJ, Brown D, Malcolm-Smith $N$. Use of ether in life-threatening acute severe asthma. Lancet $1985 ; \mathrm{i}: 187-8$.

11 Johnston RG, Noseworthy TW, Friesen EG, Yule HA, Shustack A. Isoflurane therapy for status asthmaticus in children and adults. Chest 1990;97:698-701.

12 Echeverria M, Gelb AW, Wexler HR, Ahmad D, Kenefick $P$. Enflurane and halothane in status asthmaticus. Chest 1986;89:152-4.

13 Watt I, Ledingham IM. Mortality amongst multiple trauma patients admitted to an intensive therapy unit. Anaesthesia 1984;39:973-81.

14 Parke TJ, Stevens JE, Rice ASC, Greenaway CL Bray RJ, Smith PJ, et al. Metabolic acidosis and fatal myocardial failure after propofol infusion in children: five case refailure after propofol infusion
ports. BMF 1992;305:613-6. 